\title{
Education in evidence-based health care: never a greater need
}

\section{David Nunan}

10.1136/bmjebm-2021-111792

Primary Care Health Sciences, University of Oxford, Oxford, UK

Correspondence to: Dr David Nunan, Primary Care Health Sciences, University of Oxford, Oxford OX2 6GG, UK; david.nunan@phc.ox.ac.uk

Check for updates

(1) Author(s) (or their employer(s)) 2021. No commercial re-use. See rights and permissions. Published by BMJ.

To cite: Nunan D. BMJ Evidence-Based Medicine 2021;26:212-213.

\section{Shaping the who, what, when and how for the teaching of evidence-based healthcare in the next 20 years COVID-19 era}

When we first published ${ }^{1}$ our call for revisiting efforts to teach the skills of evidence-based healthcare (EBHC) back in November 2019, "COVID-19" was absent from society's vocabulary. The aim of our call was to discuss, debate and demonstrate effective teaching of the knowledge, skills and competencies underpinning evidence-based practice in medicine and healthcare. We wanted to challenge current practice and consider the next paradigm shift in teaching and practice. Who knew how much the world would change in the months that followed.

The COVID-19 pandemic has undoubtedly been the paradigm shift to end all others. It has arguably provided the greatest stress test of evidencebased medicine, both from a public health perspective and clinical care, since the term was coined three decades ago. It has brought to the surface long-standing issues with unprecedented levels of exposure-not least the role of evidence for addressing uncertainty.

COVID-19 has been the exemplar of both the best and worst in evidence-based health decisionmaking. Profound examples of 'the best' include the RECOVERY, SOLIDARITY and PRINCIPLE trials-rapid, high-quality evidence acquisition overcoming the usual red tape that comes with clinical trials. Acting on evidence not fit for purpose and the lack of acknowledgement of uncertainty are my candidates for 'the worst'hydroxychloroquine, ivermectin and other drug cocktails as examples of the former and the role out of non-drug interventions as an example of the latter.

A key issue from an "evidence-based" perspective has been the test of our collective ability to use research evidence to inform effective decisionmaking. The urgency of the pandemic has raised many questions. We might then ask what is the value of a series of articles in answer to the question "What next for education in EBHC?" that was asked in a 'pre-COVID-19' era?

The pandemic has highlighted the need for high-quality evidence-based decision-making. Asking the right questions; acquiring the bestavailable evidence to answer them; rigorously, explicitly and fairly appraising the available evidence; clearly expressing if and how it helps reduce our uncertainties; being clear if and how the available evidence applies to practice and what needs to happen if it does not. All of these remain important if not crucial steps even during a pandemic. We just need to perform these steps with more urgency and more efficiently.

The pandemic has also re-emphasised the need for teaching the skills underpinning evidencebased decision-making and that the way we teach them may need to change . Many of the changes already made during this pandemic are likely to stay. ${ }^{2}$ Online education has taken centre stage and 'traditional' ways of teaching and learning increasingly have been challenged, including in medical education. ${ }^{3}$ I think this gives educators of evidence-based health care an interesting perspective for reflecting on the impact of the pandemic on evidence to inform better decisions and teaching the skills to do this well.

Our series of 18 selected articles submitted during the pandemic period offer insights into developments of not only the what but also the how and why in the education of evidence-based decision-making skills which remain pertinent, if not even more so, in the COVID-19 era. The topics covered read as if the authors already had their fingers on the pulse-ranging from randomised controlled trials, observational studies and evaluations of online, digital and distance EBHC learning interventions and programmes ${ }^{4-11}$ to provocative debate articles on the competencies of evidence-based decision-making that we should (and should not) focus on for educating our health professionals ${ }^{12}$ and frameworks ${ }^{13}$ and professional consensus ${ }^{14}$ to support effective education of these competences in health professional curricula.

Programme evaluation is a critical process in ensuring curricula are fit for purpose-included articles provide detailed evaluations of EBHC curricula over a 15 -year period, ${ }^{15}$ the impact of different curriculum pathways ${ }^{16}$ and important endeavours to educate EBHC skills outside of the formal curriculum. ${ }^{17}$ Another key aspect of any curriculum is assessment-it drives learning after all. If assessment drives learning, what drives teaching? Rashid et al encourage educators to consider how accreditation standards and procedures can facilitate EBHC teaching. ${ }^{18}$

The pandemic brought to the fore another issue of our times-the unprecedented power of the media to disseminate health claims. This power can be used in many ways but what about as a resource for teaching EBHC? Oxman et al describe early development of an intervention to use media stories and headlines for educating professionals how to think critically about health information. ${ }^{19}$ 
Prominent educators have spent decades developing, refining and educating on how to apply the principles of EBHC to help improve healthcare decision-making. Arguably, one of the most successful examples is the Grading of Recommendations Assessment, Development and Evaluation (GRADE) working group approach which aims to determine the confidence we can have in a body of evidence and any recommendations based on it. Kumar and Taggarsi provide a timely and positive overview of the GRADE method as a useful launchpad to discuss its relative strengths and weaknesses and how these hold up in times of greatest need. ${ }^{20}$

The pandemic has highlighted the importance of health science and research that is efficiently produced, evaluated and acted on. Hand in hand with this comes the ability to ask, find, appraise and apply evidence to support effective decisions. These abilities are essential skills-skills that need to be taught. Where there is a need to be taught, there is a need for people to teach. The final article in the series aims to aid EBHC educators in this mission. Through collaboration and consensus, our peers come together to provide aspiring EBHC teachers a resource of their go-to articles in support of effective and inspirational teaching and education. ${ }^{21}$

Twitter David Nunan@dnunan79

Contributors The author oversaw the series collection and drafted the editorial.

Funding The author has not declared a specific grant for this research from any funding agency in the public, commercial or not-for-profit sectors.

Competing interests None declared.

Patient consent for publication Not required.

Provenance and peer review Not commissioned; internally peer reviewed.

\section{ORCID iD}

David Nunan http://orcid.org/0000-0003-4597-1276

\section{References}

1 Nunan D, Jackson R, Heneghan C. What next for education in evidencebased healthcare? A call for submissions. BMJ Evid Based Med 2020;25:1.7-2

2 The COVID-19 pandemic has changed education forever. this is how, 2021. Available: https://www.weforum.org/agenda/2020/04/coronaviruseducation-global-covid19-online-digital-learning/

3 Gordon M, Patricio M, Horne L, et al. Developments in medical education in response to the COVID-19 pandemic: a rapid BEME systematic review: BEME guide No. 63. Med Teach 2020;42:1202-15.

4 Dawes D, Rusticus S, Beck C, et al. Development of five online modules for teaching evidence-informed healthcare: the West coast interprofessional clinical knowledge evidence Disseminator (WICKED) project. BMJ Evid Based Med 2021;26:237-40.

5 Arienti C, Lazzarini SG, Pollet J, et al. Students 4 best evidence as a digital problem-based learning method to improve evidence-based practice competencies in undergraduate physiotherapy students: an observational study. BMJ Evid Based Med 2021;26:251-2.

6 Hoffmann TC, Del Mar C SR, Santhirapala R, et al. Teaching clinicians shared decision making and risk communication online: an evaluation study. BMJ Evid Based Med 2021;26:253.

7 Martinez C, Tilson JK. Controlled comparison of a flipped classroom evidence-based practice course delivered online or on-campus. BMJ Evid Based Med 2021;26:219-23.

8 McCall MC, Fanshawe TR, McCartney D, et al. Online supplementation for teaching evidence-based medicine: feasibility of a randomised-controlled trial. BMJ Evid Based Med 2021;26:254.

9 McCaul M, Durao S, Kredo T. Evidence synthesis workshops: moving from face-to-face to online learning. BMJ Evid Based Med 2021;26:255-60.

10 Pacheco RL, Bagattini AM, Pachito DV, et al. Distance practical course on systematic reviews to support decisions of Brazilian regulatory agency for supplementary healthcare system. BMJ Evid Based Med 2021;26:261-2.

11 Polanczyk CA, de Quadros AM, Fontanella AT. Ebm distance learning course to support Judicial decisions on healthcare: a case study. BMJ Evid Based Med 2021;26:266-7.

12 Tikkinen KAO, Guyatt GH. Understanding of research results, evidence summaries and their applicability-not critical appraisal-are core skills of medical curriculum. BMJ Evid Based Med 2021;26:231-3.

13 Lehane E, Agreli H, O' Connor S. Building capacity: getting evidencebased practice into healthcare professional curricula. BMJ Evid Based Med 2021;26:246.

14 Araujo GA, Correia LCL, Siqueira JR, et al. Consensus on evidence-based medicine curriculum contents for healthcare schools in Brazil. BMJ Evid Based Med 2021;26:248.

15 Korownyk CS, Allan GM, McCormack J. Successes, lessons and opportunities: 15-year follow-up of an integrated evidence-based medicine curriculum. BMJ Evid Based Med 2021;26:241-5.

16 Menard L, Blevins AE, Trujillo DJ. Integrating evidence-based medicine skills into a medical school curriculum: a quantitative outcomes assessment. BMJ Evid Based Med 2021;26:249-50.

17 Rocha GFA, Pacheco RL, Latorraca CdeOC. First academic League of EBM in Brazil: experience report. BMJ Evid Based Med 2021;26:263-5.

18 Rashid A, Finnikin S, Tackett S. Accreditation drives teaching: evidencebased medicine and medical education standards. BMJ Evid Based Med 2021;26:216-8.

19 Oxman M, Habib L, Jamtvedt G. Using claims in the media to teach essential concepts for evidence-based healthcare. BMJ Evid Based Med 2021;26:234-6.

20 Kumar A, Taggarsi M. GRADEing quality of evidence and its importance in evidence-based practice. BMJ Evid Based Med 2021;26:228-30.

21 Nunan D, Lindblad A, Widyahening IS. Ten papers for teachers of evidence-based medicine and health care: Sicily workshop 2019. BMJ Evid Based Med 2021;26:224-7. 